SHR Notes and Comments

\title{
A 1706 Manifesto for an Armed Rising against Incorporating Union
}

\begin{abstract}
This paper presents a draft manifesto by Robert Wylie, minister of Hamilton parish, for a popular Presbyterian rising designed to halt the ratification of incorporating union by the Scottish parliament in its 1706-07 session. The document has been preserved in Robert Wodrow's extensive collection of papers held by the National Library of Scotland. Speaking in the name of the 'free people' of Scotland, the manifesto demands new elections to produce a parliament more representative of national opinion on incorporation. The new parliament would proceed to confirm the Hanoverian succession with limitations on monarchical powers. The document illustrates common arguments against incorporating union held by some Presbyterians in 1706-07 and indicates the importance of the settlement of the Hanoverian succession with limitations as an alternative to incorporating union. The document demonstrates the political activism of clergy like Wylie, acting in cooperation with opposition leaders in parliament.
\end{abstract}

Recent studies have shown how religious concerns led Scottish Presbyterians to divide over the question of incorporation during the parliamentary session of 1706-07. Though incorporating union offered a means of confirming Sophia, electress of Hanover as Scotland's successor to Queen Anne and thus sustaining the Protestant Revolution interest against the threat of a Jacobite restoration, some felt that the covenants of 1638 and 1643 demanded the preservation of the Scottish realm and parliament and made an entire union with Anglican England impossible. ${ }^{1}$ There was ferocious debate in the Commission of the General Assembly on how far the institutional church

\footnotetext{
${ }^{1}$ Presbyterian attitudes towards incorporating union have been discussed in specialised and general studies including Colin Kidd, 'Religious Realignment Between the Revolution and the Union' in J. Robertson (ed.), A Union for Empire: Political Thought and the British Union of 1707 (Cambridge, 1995); John Robertson, 'An elusive sovereignty: the course of the union debate in Scotland 1698-1707' in Robertson (ed.), Union for Empire; Christopher A. Whatley with Derek Patrick, The Scots and the Union (Edinburgh, 2006); Jeffrey Stephen, Scottish Presbyterians and the Act of Union 1707 (Edinburgh, 2007); Karin Bowie, Scottish Public Opinion and the Anglo-Scottish Union, 1699-1707 (Woodbridge, 2007); Karin Bowie, 'Popular resistance, religion and the Union of 1707' in T. M. Devine (ed), Scotland and the Union, 1707-2007 (Edinburgh, 2008); Derek J. Patrick, 'The Kirk, Parliament and the Union, 1706-07', Scottish Historical Review [SHR] 87 (2008 supplement), 94-115; Derek J. Patrick and Christopher A. Whatley, 'Persistence, principle and patriotism in the making of the Union of 1707: the Revolution, Scottish Parliament and the squadrone volante', History 92:2 (2007), 162-186; Clare Jackson, 'Conceptions of nationhood in the Anglo-Scottish Union debates of 1707', SHR 87 (2008 supplement), 61-77; Colin Kidd, Union and Unionisms: Political Thought in Scotland, 1500-2000 (Cambridge, 2008), 51-93; Clare Jackson, 'Union Historiographies' in T. M. Devine and J. Wormald (eds), Oxford Handbook of Modern Scottish History (Cambridge, 2012), 344-345.
} 
should resist incorporating union. ${ }^{2}$ Those clergy and elders promoting greater resistance included Robert Wylie [or Wyllie] of Hamilton parish, a leading clergyman and the apparent author of the document presented here. Scribbled in Wylie's hand late in 1706, this is a draft manifesto for an armed rising designed to prevent the ratification of the treaty of union. The text is aligned closely with parliamentary affairs, especially attempts by William Johnstone, first marquis of Annandale, and James Hamilton, fourth duke of Hamilton, to promote a settlement of the Hanoverian succession with limitations on the prerogative of the successor as an alternative to incorporating union. Speaking in the name of the 'free people' of Scotland, the manifesto indicates a plan for an orchestrated gathering of armed supporters who would demand that parliament lay aside the union treaty on the grounds that its votes did not constitute true national consent. The queen would be asked to call elections to purge traitorous members, creating a parliament more responsive to a professed national desire for an act settling the Hanoverian succession with limitations. As the feasibility of an armed rising has been considered elsewhere, this note will focus on explicating the context of the manifesto, its arguments against incorporation and its call for a succession act. ${ }^{3}$ The manifesto demonstrates the deep engagement of clergy like Wylie in national affairs, the elaboration of anti-incorporation themes from a Presbyterian point of view and the counter-factual potential of attempts to promote a succession act as an alternative to incorporating union.

The continuation of the regal union with additional limitations on the Scottish monarch had been proposed in acts passed in 1703 and 1704. After the death of Anne's last child in 1700, the English parliament had named the electress Sophia of Hanover, a Protestant grand-daughter of James VI, as Anne's heir in the 1701 Act of Succession. Though this act assumed that Sophia would take up the Scottish crown, the failure of union talks in the winter of 1702-03 left the succession open in Scotland. The Act of Security laid down procedures by which the Scottish parliament would install a Protestant successor at Anne's death, with a requirement that the estates legislate for 'conditions of government' to secure Scotland's sovereignty and reduce English influence on Scottish affairs before accepting the English successor onto the Scottish throne. ${ }^{4}$ A range of constitutional conditions designed to limit the royal prerogative and enhance the powers of the Scottish

\footnotetext{
${ }^{2}$ Stephen, Scottish Presbyterians, 44-61; Bowie, Scottish Public Opinion, 118-19, 135.

${ }^{3}$ Karin Bowie, 'Popular resistance and the ratification of the Anglo-Scottish treaty of union', Scottish Archives 14 (2008), 10-26; Stephen, Scottish Presbyterians, 157-72; Rosalind Carr, 'Gender, National Identity and Political Agency in Eighteenth-Century Scotland', University of Glasgow PhD thesis (2008), 103-107; Whatley, Scots and the Union, 278-81; Allan I. Macinnes, Union and Empire: The Making of the United Kingdom in 1707 (Cambridge, 2007), 290-91.

${ }^{4}$ Keith Brown (gen. ed.), Records of the Parliaments of Scotland [hereafter RPS], www.rps.ac.uk, 'Act for the security of the kingdom', RPS 1704/7/68, 5 August 1704. Versions of the act were passed in 1703 and 1704, receiving the royal assent in 1704 . On the passage of the Act of Security in 1703, see Keith Brown, 'Party politics and parliament: Scotland's last election and its aftermath, 1702-3' in Keith Brown and Alastair Mann (eds), Parliament and Politics in Scotland, 1567-1707 (Edinburgh, 2005), 278-85.
} 
parliament were elaborated in speeches, overtures and tracts by Andrew Fletcher of Saltoun, Patrick Hume, first earl of Marchmont, John Hamilton, Lord Belhaven and others from 1703 to $1705 .{ }^{5}$ As John Young has stressed, these proposals were informed by limitations on the Scottish monarch secured in 1640-41 and 1689-90. ${ }^{6}$ Fletcher proposed thoroughgoing reforms for annually elected parliaments in which all legislation received an automatic royal assent and parliament chose when to adjourn itself. An executive committee of the estates would have a role in governing Scotland, parliamentary consent would be needed for the making of war and treaties and the estates would appoint all state officers. ${ }^{7}$ In a 1703 overture, Marchmont envisaged less radical limitations, including regular elections, parliamentary consent in the selection of office-holders and a requirement that the next monarch pursue a treaty between Scotland and England for a communication of trade by which the Scots would no longer be treated as alien traders in England and its colonies. ${ }^{8}$ Acts for a number of conditions and limitations were considered by parliament between 1703 and 1705, including triennial elections and parliamentary consent for state appointments, though the only act to receive the royal assent was the $1703 \mathrm{Act}$ anent War and Peace requiring parliamentary approval for monarchical declarations of war and treaties of peace. ${ }^{9}$

As Paul Scott and Allan Macinnes have shown, the instructions given to the queen's commissioners in 1704 and 1705 asked them to secure the Hanoverian succession with modest limitations, including parliamentary ratification of crown nominations to state office. ${ }^{10}$ Anne's resistance to more strict limitations, the Jacobite Cavaliers' discomfort with the Hanoverian succession and factional realignments under changing ministries meant that the queen's

\footnotetext{
${ }^{5}$ John R. Young, 'The Scottish parliament and the covenanting heritage of constitutional reform' in A. I. Macinnes and J. Ohlmeyer (eds), The Stuart Kingdoms in the Seventeenth Century: Awkward Neighbours (Dublin, 2002), 242-49; Andrew Fletcher, Political Works, ed. J. Robertson (Cambridge, 1997), 129-73; [George Ridpath], An Historical Account of the Antient Rights and Power of the Parliament of Scotland. Humbly Offer'd to the Consideration of the Estates, When They Come to Settle Limitations for the Next Successor ([Edinburgh], 1703); [John Hamilton, Lord Belhaven], A Speech in Parliament Touching Limitations ([Edinburgh, 1703]); [Robert Wylie], A Speech Without Doors, Concerning Toleration ([Edinburgh, 1703]); [Patrick Hume, first earl of Marchmont], Overture by Way of Act Concerning the Succession ([Edinburgh], 1703); [James Johnstone], Reflections on a Late Speech by the Lord Haversham (London, 1704); [John Hamilton, Lord Belhaven], The Lord Belhaven's Speech in Parliament, the $17^{\text {th }}$ of July 1705 ([Edinburgh, 1705]). See also Whatley, The Scots and the Union, 209-11; Macinnes, Union and Empire, 258-66.

${ }^{6}$ Young, 'The Scottish parliament'.

${ }^{7}$ A. Fletcher, Political Works, ed. J. Robertson (Cambridge, 1997), pp. 131-2, 138-9; P. H. Scott, Andrew Fletcher and the Treaty of Union (Edinburgh, 1994), 83-84; Macinnes, Union and Empire, 267-9.

${ }^{8}$ [Marchmont], Overture by Way of Act.

${ }^{9}$ Young, 'Scottish parliament', 246-9; RPS 1703/5/52, 'Procedure: drafts acts read and to lie on the table', 1 June 1703; RPS A1705/6/17, 'Overture for limitations on the successors of the queen', 15 August 1705; RPS 1705/6/61, 'Procedure: debate over triennial act', 22 August 1705; RPS 1705/6/59, 'Procedure: approval of act for appointments and officers of state', 21 August 1705; RPS 1703/5/193, 'Act anent peace and war', 16 Sept 1703. This responded to grievances arising from the 1697 Peace of Ryswick and the queen's use of the royal prerogative to declare war on France in 1702.

${ }^{10}$ Scott, Andrew Fletcher, 108; Macinnes, Union and Empire, 273. This instruction followed the precedent of an act of 1641. Young, 'Scottish Parliament', 248.
} 
commissioners could not muster a majority for the succession. In parliament, opinions on limitations varied, with some fearing these measures would only worsen Anglo-Scottish relations. ${ }^{11}$ In 1705, the royal commissioner, John Campbell, first duke of Argyll, turned to an act for treaty talks to fulfil the terms of the English Alien Act, which threatened economic sanctions if the Scottish parliament did not authorise either the succession or talks for a union treaty. For many members, an act for a treaty offered the possibility that negotiations might lead to a treaty for a communication of trade or federal union--or nothing at all, as in 1668-70, 1689 and 1702-03. ${ }^{12}$

When talks by the queen's hand-picked negotiators led to a treaty for incorporating union, the ratification of the Hanoverian succession with limitations re-emerged as an alternative for those wishing to maintain a separate Scottish realm and parliament in a reformed Union of Crowns. In July 1706, Robert Wylie expressed his view to the duke of Hamilton that the 'moatley Ministery' (the Presbyterian New Party ministry of 1704, known by 1706 as the squadrone volante) plus the 'honest presbiterians' of the Country party could join together and 'overmatch the Court'. ${ }^{13}$ Derek Patrick has demonstrated the Hanoverian sympathies of some in the Country opposition who rejected the treaty but voted for the article on the Hanoverian succession. ${ }^{14}$ The queen' s ministry, however, now led by James Douglas, second duke of Queensberry, secured a predominantly Presbyterian coalition for incorporation by drawing the squadrone volante into an alliance with the Court party. ${ }^{15}$ By November, it was clear that this combination could only be overcome with aggressive resistance.

The document below has been found in an extensive collection of manuscript papers gathered by Robert Wodrow, minister of Eastwood parish near Glasgow and formerly librarian at the University of Glasgow, for his two-volume History of the Suffering of the Church of Scotland from the Restoration to the Revolution, published in Edinburgh in 1721 and 1722. Though his Presbyterian history stopped at the Revolution, Wodrow collected the papers of prominent ministers active after this period. ${ }^{16}$ Archived by the National Library of Scotland, Quarto LXXIII of this collection includes a

\footnotetext{
${ }^{11}$ Lockhart of Carnwath, 'Scotland's Ruine', 39; Mackay, The Duke of Queensberry, 181.

${ }^{12}$ Karin Bowie, 'Publicity, Parties and Patronage: Parliamentary Management and the Ratification of the AngloScottish Union', SHR 87 (2008 supplement), 86-90.

${ }^{13}$ Edinburgh, National Records of Scotland [NRS], GD406/1/9747, Robert Wylie to duke of Hamilton, 1 July 1706.

${ }^{14}$ Patrick, 'The Kirk, Parliament and the Union', 110.

${ }^{15}$ On this coalition, see Derek J. Patrick and Christopher A. Whatley, 'Persistence, principle and patriotism in the making of the Union of 1707: the Revolution, Scottish Parliament and the squadrone volante', History 92:2 (2007), 162-186; P. W. J. Riley, The Union of England and Scotland (Manchester, 1978), 271-81. By contrast, Collins Mackay has downplayed the importance of the squadrone, emphasising instead Queensberry's wooing of James Graham, fourth marquis of Montrose, the disbursal of rewards to supporters and the managerial talents of his lieutenant John Erskine, sixth earl of Mar, combined with the growth of unionist sentiment in parliament. Collins Mackay, The Duke of Queensberry and the Union of Scotland and England: James Douglas and the Act of Union of 1707 (Youngstown, N.Y., 2008), 163, 174-75, 177, 181, 193, 197, $200-08$.

${ }^{16}$ L. A. Yeoman, 'Wodrow, Robert (1679-1734)', Oxford Dictionary of National Biography, Oxford University Press, 2004 [http://www.oxforddnb.com/view/article/29819, accessed 19 Feb 2015].
} 
set of papers identified as those of Robert Wylie, in which this document appears with other papers from the 1706-7 period. The paper is not signed but the handwriting appears to be a rougher version of that found on more carefully written holograph letters by Robert Wylie. ${ }^{17}$ Marginal additions and crossed-out words indicate that the document is a first draft. No fair or printed copy of the text has been found. As will be shown, the content of the manifesto is similar to Wylie's published works and letters. Together these factors strongly support an attribution to Wylie.

The involvement of the minister of Hamilton parish in a plan to disrupt parliament was made possible by the church's reliance on, and vulnerability to, acts of parliament. Though Presbyterian ideology prevented clerics from holding civil office or sitting in parliament, the post-Revolution church sought parliamentary sanction for its activities and privileges and many clergy interested themselves in matters relating to the security of the church and the welfare of the nation. ${ }^{18}$ Political activism on the part of clergy was facilitated by structural overlaps between the ecclesiastical and civil spheres. Church courts, from parish kirk sessions to regional presbyteries and synods and the national General Assembly with its smaller executive Commission, contained lay elders as well as clergy. As Dougal Shaw has pointed out for Edinburgh, baillies sat on burgh kirk sessions and civil deacons of crafts and guilds might hold the position of elder or church deacon, 'eliding the spiritual and the secular'. ${ }^{19}$ In Linlithgow, provost and parliamentary commissioner Walter Steuart of Pardovan served as an elder on the Commission and was deeply involved in local church governance. ${ }^{20}$ Statutes passed in the decade after the 1689 Revolution required the cooperation of local proprietors and burgh magistrates with kirk sessions in the appointment and payment of clergy and schoolmasters, the administration of poor relief and the maintenance of the fabric of the parish church and school. ${ }^{21}$ From 1704, magistrates, proprietors and clergy were responsible for a new

\footnotetext{
${ }^{17}$ A reproduction of a letter written by Wylie can be seen in Raffe, Culture of Controversy, 204.

${ }^{18}$ James Kirk (ed.), The Second Book of Discipline (Glasgow and Edinburgh, 2005), 170-72. On the political activity of the post-Revolution church, see Alasdair Raffe, 'Presbyterianism, secularization and Scottish politics after the Revolution of 1688-90', Historical Journal 53:2 (June 2010), 317-37; Jeffrey Stephen, 'Defending the Revolution: the Church of Scotland and the Parliament, 1689-95', Scottish Historical Review 89,1: 227 (April 2010), 19-53.

${ }^{19}$ Dougal Shaw, 'St. Giles' church and Charles I's coronation visit to Scotland', Historical Research 77:198 (Nov. 2004), 492.

${ }^{20}$ Patrick, 'The Kirk, Parliament and the Union', 98. Pardovan's deep involvement in the church is reflected in his handbook for church officers published in 1709: Walter Steuart of Pardovan, Collections and observations methodiz'd; concerning the worship, discipline, and government of the Church of Scotland (Edinburgh, 1709). See Bowie, Scottish Public Opinion, 135 on lay attendance at the 1706 Commission of the General Assembly. The level of lay attendance at the Commission bears some comparison to the packing of the 1638 General Assembly with 'ruling elders' sympathetic to the Covenant, though in 1706 both Court and Country elders came to the Commission. Roger Mason, 'The aristocracy, episcopacy and the Revolution of 1638' in T. Brotherstone (ed.), Covenant, Charter and Party: Traditions of Revolt and Protest in Modern Scottish History (Aberdeen, 1989).

${ }^{21}$ Laurence A. B. Whitley, A Great Grievance: Ecclesiastical Lay Patronage in Scotland until 1750 (Eugene OR, 2013), 86-90.
} 
national militia based in burghs and parishes. ${ }^{22}$ As will be seen, leading nobles could have close links with parish clergy, especially where landownership was concentrated in the hands of one family or kin nexus. In the post-Revolution church as well as the parliament, differences in opinion on royal policy led to the appearance of Court and Country polarities. In 1703, John Dalrymple, second earl of Stair, described a parliament divided between those 'displeased with the measures of the Government' and those 'willing to support it in conjunction with the ministers of State'. ${ }^{23}$ Pamphlets written by Wylie and his colleague Archibald Foyer of Stonehouse parish in Lanarkshire applied Court and Country distinctions to the institutional church, as did an account of the union parliament composed by Steuart of Pardovan. ${ }^{24}$ For Sir John Clerk of Penicuik, Country opposition arose from a 'spirit of faction', but for Wylie, the clergy who cooperated with the Court were 'Juggling and time serving' brethren. ${ }^{25}$

A particular hotbed of political activity can be identified in the synod of Glasgow and Ayr, reflecting not just the historic strength of Presbyterian culture and the covenants in this region but also the sympathies and influence of Scotland's most senior noble family, the Hamiltons. ${ }^{26}$ Anne, duchess of Hamilton, her husband William, third duke of Hamilton, and several of her children were closely involved in national politics. ${ }^{27}$ William represented Presbyterian interests as an oppositional figure during the 1670 s and presided over the 1689 Revolution Convention. ${ }^{28}$ Initially Jacobite at the Revolution, Anne's son James, fourth duke of Hamilton, cultivated both Jacobite and Presbyterian adherents as a leader of the Country opposition from 1699. Two other sons sat in parliament: John Hamilton, earl of Ruglen voted with the Country party while Charles, second earl of Selkirk, gravitated to the 1704 New Party but voted with his brother the duke against the union in 1706 . Their mother the duchess used her hereditary position as sheriff of Lanarkshire to help organise

\footnotetext{
${ }^{22}$ RPS 1704/7/68, 'Act for the security of the kingdom', 5 August 1704.

${ }^{23}$ John Murray Graham, Annals and Correspondence of the Viscount and First and Second Earls of Stair, 2 vols, (Edinburgh and London, 1875), i, 203.

${ }^{24}$ [Robert Wylie], Letter from a gentleman in the city to a minister in the country ([Edinburgh], 1703), 14; PhiloCaledonius [Archibald Foyer], Scotland's present duty: or, a call to the nobility, gentry, ministry and commonality of this land ([Edinburgh], 1700), 5; Edinburgh, National Library of Scotland [NLS], Wodrow Quarto LXXV, Walter Steuart of Pardovan, 'A short account of the proceedings of the last session of the Scots parliament', ff. 138-60.

${ }^{25}$ Sir John Clerk of Penicuik, History of the Union of Scotland and England, trans. and ed. D. Duncan (Edinburgh, 1993), 99; NLS Wodrow Folio 28, vol. 2, Robert Wylie, 'Scruples by way of queries relating to the day of thanksgiving \& publick prayers appointed to be kept', f. $175 \mathrm{v}$.

${ }^{26}$ The synod encompassed the presbyteries of Ayr, Irvine, Paisley, Greenock, Hamilton, Lanark, Dumbarton and Glasgow.

${ }^{27}$ Anne held her ducal title in her own right, having inherited it from her uncle the second duke in 1651. For more on Anne, see Rosalind K. Marshall, The Days of Duchess Anne (East Linton, 2000).

${ }^{28}$ Rosalind K. Marshall, 'Hamilton [Douglas], William, third duke of Hamilton (1634-1694)', Oxford Dictionary of National Biography, Oxford University Press, 2004 [http://www.oxforddnb.com/view/article/7935, accessed 19 Feb 2015].
} 
lawful resistance to incorporation. ${ }^{29}$ Followers of the fourth duke included the Jacobite George Lockhart of Carnwath, commissioner for Lanarkshire from 1703, whose memoirs provide an insider's perspective on Country party activities and aspirations. ${ }^{30}$ Hamilton influence reached beyond Lanarkshire through the duke's nephew, John Cochrane, fourth earl of Dundonald, who headed the signatures of an address against in corporation from the shire of Renfrew. ${ }^{31}$ Hamilton's devoutly Presbyterian sister Katherine was married to John Murray, first duke of Atholl in Perthshire, a leading nobleman associated with the Jacobite Cavaliers and a prominent figure in the Country party in 1706-07. ${ }^{32}$ Hamilton's cousin William Johnston, first marquis of Annandale in southwest Scotland served as president of the Parliament and commissioner to the General Assembly under William and held offices including privy seal, president of the privy council and secretary of state under Anne. He left government when the queen's new ministry pursued incorporating union instead of the Hanoverian succession in $1705 .^{33}$

The first charge at the church in Hamilton, located next to Hamilton Palace, was held by Robert Wylie from 1692 to his death in 1715. Wylie was a respected clergyman, characterised by his friend Wodrow as pious, educated and refined. ${ }^{34}$ He was the son of Thomas Wylie, a Protester minister deposed at the Restoration and later indulged in the parish of Fenwick near Kilmarnock in east Ayrshire. ${ }^{35}$ Wylie's correspondence shows that he worked to advance what he saw as Presbyterian and national interests by advising and cooperating with the Hamiltons. ${ }^{36}$ In 1702, for example, on the accession of Queen Anne, he provided two drafts of a loyal address for the consideration of the duchess and her son. ${ }^{37}$ Though the duchess, as the parish heritor, paid Wylie's stipend, Wylie sought to maintain a collaborative rather than dependent relationship. In June 1705 when she asked him to go to Edinburgh to consult with her son the duke, he refused money for the

\footnotetext{
${ }^{29}$ For more on the Hamiltons and Anne's political activity, see Carr, 'Gender', 81-107.

${ }^{30}$ George Lockhart, 'Scotland's Ruine': Lockhart of Carnwath's Memoirs of Union, ed. D. Szechi, (Aberdeen, 1995); Christopher Whatley and Derek Patrick, 'Contesting interpretations of the Union of 1707: the abuse and use of Lockhart of Carnwath's memoirs', Journal of Scottish Historical Studies 27 (2007), pp. 24-47.

${ }^{31}$ Bowie, Scottish Public Opinion, 121-2; NRS Supplementary Parliamentary Papers PA 7/28/19, Renfrewshire.

${ }^{32}$ Carr, 'Gender', 107-118; Nicola Cowmeadow, "'Your Politick, self designing sister": The role of Katherine, first Duchess of Atholl in the Scottish elections of 1702', Parliaments, Estates and Representation 33:1 (April 2013), 1-19.

33 Duncan Adamson, 'Johnstone, William, first marquess of Annandale (1664-1721)', Oxford Dictionary of National Biography (Oxford University Press, 2004; online edn, Jan 2008), [http://www.oxforddnb.com/view/article/14970, accessed 23 Feb 2015]; Lockhart, 'Scotland's Ruine', 110. Annandale's departure reflected rivalry with Court nobles as well as opposition to incorporating union. Whatley, The Scots and The Union, 27.

${ }^{34}$ Hew Scott (ed.), Fasti Ecclesiae Scoticanae, 7 vols. (Burlington, 2011), iii, 260.

${ }^{35}$ For Thomas Wyllie, see ibid., 94.

${ }^{36}$ NRS, Correspondence of the dukes of Hamilton, 1563-1712, GD406/1/7387, 7815, 7819, 4948, 4944, 4900, 7098, 5297, 7134, 9747, 9731, 7125.

${ }^{37}$ NRS, Correspondence of the dukes of Hamilton, GD 4061/14948, J. Hamilton to duke of Hamilton, 9 January 1702.
} 
journey and she 'promised never to desire him to make such a Jornie as this again'. ${ }^{38}$ In June 1706, Selkirk reported to his brother the duke that he could 'fish nothing out of' Wylie on what the Presbyterian clergy would do on the union question, other than that 'if the Parliament will do righteous things they will joyne heartily with them against an incorporating union. ${ }^{39}$ After the start of the parliamentary session on 3 October 1706 , the duke wrote several urgent but unsuccessful letters asking Wylie to come to Edinburgh and expressing his disappointment when Wylie arrived too late to help support a motion in parliament for a national fast. ${ }^{40}$

Robert Wylie was a member of the presbytery of Hamilton and synod of Glasgow and Ayr and at various times served as a presbyterial representative on the Commission of the General Assembly. Surviving pamphlets and church court records demonstrate regular politicking by Wylie and other clergy and elders from his synod on a range of issues. In October 1700, Wylie's synod of Glasgow and Ayr responded to the plight of the Company of Scotland and its Darien colony by resolving to encourage local parliamentary commissioners and the Commission of the General Assembly to send addresses to parliament. ${ }^{41}$ The Commission did not address, but eighteen addresses from shires and burghs were read on 9 January 1701. Of these, three originated in the bounds of Wylie's synod, from the shires of Ayr and Renfrew and the inhabitants of Glasgow. ${ }^{42} \mathrm{~A}$ concurrent pamphlet attributed to Archibald Foyer called on the estates and commons of Scotland to support the Company and its colony. ${ }^{43}$

As Alasdair Raffe has demonstrated, though the post-Revolution church reached an accommodation with William II on the calling of meetings of the General Assembly by the monarch, a minority continued to campaign for an assertion of the church's 'intrinsic right' to assemble on its own authority. ${ }^{44}$ In 1701, the synod of Glasgow and Ayr considered sending an address to William

\footnotetext{
${ }^{38}$ NRS, Correspondence of the dukes of Hamilton, GD406/1/7134, duchess of Hamilton to duke of Hamilton, 25 June 1705.

${ }^{39}$ NRS, Correspondence of the dukes of Hamilton, GD406/1/9110, Charles earl of Selkirk to duke of Hamilton, 10 June 1706.

${ }^{40}$ NLS, Wodrow MSS Quarto XXX, duke of Hamilton to Robert Wylie, 8 October 1706, f. 271; NRS, Correspondence of the dukes of Hamilton, GD406/1/7127 duke of Hamilton to Robert Wylie, 12 October 1706. On the fast, see Patrick, 'The Kirk, Parliament and the Union', 98-99.

${ }^{41}$ NRS, Minutes of the synod of Glasgow \& Ayr, CH2/464/1, October 1700, 271.

${ }^{42}$ RPS A1700/10/25-42, 'Petitions', 9 January 1701. Bowie, Scottish Public Opinion, 58-59; John Young, 'The Scottish Parliament and the politics of empire: Parliament and the Darien project, 1695-1707', Parliaments, Estates and Representation 27:1, 181-4.

${ }^{43}$ Philo-Caledon [Archibald Foyer], Scotland's present duty: or, a call to the nobility, gentry, ministry, and commonality of this land, to be duely affected with, and vigorously to act for, our common concern in Caledonia ([Edinburgh], 1700). Kathleen Middleton has confirmed Foyer's engagement in politics on behalf of the Revolution and covenanting interest. Kathleen Middleton, 'The Minister and the Ex-Dragoon: Adjusting to the Revolution Settlement in Early Eighteenth-Century Lanarkshire', Scottish Religious Cultures Network seminar series, University of Glasgow, 24 February 2014.

${ }^{44}$ Raffe, 'Presbyterianism'. Scottish monarchs did not accept the church's right to assemble without royal consent as asserted in the Second Book of Discipline; Kirk(ed.), Second Book, 175.
} 
on this issue. ${ }^{45}$ When the issue flared up again in 1703 under Anne, Robert Wylie published an anonymous pamphlet defending the 'seasonable zeal' of his synod in asserting the church's powers and accused moderate ministers of being 'hired to keep Presbytry under the Hatches'. ${ }^{46}$ The issue remained current in April 1706 when Wylie's presbytery of Hamilton sent an overture to the General Assembly urging that presbyteries be instructed to address the Scottish parliament for a resolution of the question of the church's right to meet without royal consent. ${ }^{47}$

The involvement of churchmen in political affairs was stimulated in 1703 by proposals for Episcopalian toleration. An address from the Commission of the General Assembly urged parliament to reject toleration while a number of clergy published responses to Episcopalian tracts. ${ }^{48}$ Three anonymous pamphlets from this period have been attributed to Wylie. ${ }^{49}$ Wylie and other Presbyterian writers stressed the danger presented by toleration to the constitutional settlement of 1689-90, characterising Episcopalians as Jacobites conspiring with high church English Tories to overturn the Revolution. ${ }^{50}$ For Wylie and his colleagues, the question of toleration was not an abstract matter of conscience but a political issue of the greatest significance, requiring a robust response. $^{51}$

Clergy and elders also responded to Queen Anne's pursuit of closer union. When the Scottish parliament authorised negotiations for union in 1702, Walter Steuart of Pardovan made a formal protestation against the act's failure to cite the Claim of Right as a bar on any return to prelacy through closer union. ${ }^{52}$ Though Steuart of Pardovan generally supported Court measures, he opposed union in 1702 and $1706-7$ on religious grounds..$^{53}$ During the union talks of 1702-03, the synod of Glasgow and Ayr ordered local clergy to make a public statement of their commitment to the Presbyterian Church. ${ }^{54}$ In 1705, Archibald Foyer circulated manuscript 'overtures for preserving our Religion and liberties in Scotland from French designs and English encroachments'. This included a call for synods to ask the General Assembly to address parliament for a renewal of the National

\footnotetext{
${ }^{45}$ NRS, Minutes of the synod of Glasgow \& Ayr, CH2/464/1, 285-6.

${ }^{46}$ [Robert Wylie], Letter from a gentleman in the city, to a minister in the country ([Edinburgh], [1703]), 2, 4.

${ }^{47}$ NLS Wodrow MSS Quarto LXXIII, Overture to Assembly 1706, f. 264.

${ }^{48}$ Bowie, Scottish Public Opinion, 36-9, 60; Bowie, 'Publicity, parties and patronage', 85.

${ }^{49}$ [Robert Wylie], A speech without doors, concerning toleration ([Edinburgh], [1703]), A short answer to a short paper ([Edinburgh], 1703), A short answer to a large paper ([Edinburgh], [1703]).

${ }^{50}$ [Wylie], A speech without doors. See also [Bannatyne], Letter from a Presbyterian minister.

${ }^{51}$ The Presbyterians argued that the Episcopalians did not differ from them in confessional beliefs but only on matters of church government and therefore did not require toleration on the grounds of conscience. Raffe, 'Presbyterians and Episcopalians', 571.

${ }^{52}$ RPS 1702/6/52, 'Procedure: dissent from act concerning union', 25 June 1702.

${ }^{53}$ P. W. J. Riley, The Union of England and Scotland (Manchester, 1978), 332; Patrick 'The Kirk, Parliament and the Union', 113.

${ }^{54}$ [Robert Wylie], A letter from a member of the commission of the late General Assembly, to a minister in the country (1707), 7-8.
} 
Covenant. Foyer's overture recommended that the address be drafted by 'R. W.', probably meaning Robert Wylie. $^{55}$

From the summer of 1706, Robert Wylie's correspondence with the duke of Hamilton and two influential London-based Presbyterian pamphleteers, James Hodges and George Ridpath, shows that he was at the centre of a burgeoning print campaign against the union. ${ }^{56}$ Wylie published three tracts, in July, November and January, to influence the union debates. His engagement in sophisticated constitutional politics is indicated by his July tract which used legal opinions published by former Lord Advocates to argue that Parliament could not overturn the fundamental laws and liberties of the kingdom without the consent of its constituents. ${ }^{57}$ This argument appeared also in his second tract along with an attack on what he saw as the inadequacies of a draft act to secure the Scottish Presbyterian church in a united kingdom. ${ }^{58}$ In January, when it was clear that the treaty would be ratified, Wylie's final tract urged synods to form a public bulwark against the dangers of incorporation through a repetition of the public testimonies ordered by his synod in $1702 .^{59}$

Besides pamphleteering, Wylie and his synod and presbytery were prominent in the initiation of other forms of opposition to the treaty of union in 1706-07. In a letter to the duke of Hamilton in July, Wylie reported that 'some pains hath been taken to set on foot a correspondence' among the clergy and 'it is hoped that all will take the alarm' ${ }^{60}$ On 1 October 1706 , the synod of Glasgow and Ayr resolved to hold prayer meetings in its presbyteries and kirk sessions on the issue of union and to urge other synods to do the same. It further recommended that the Commission of the General Assembly petition parliament on behalf of the church's interests in union and urge a national fast. ${ }^{61}$ The Commission of the General Assembly produced an address to parliament on 17 October requesting that the Scottish church be secured in the event of incorporation. Joining the Commission shortly after this, Wylie and other opponents of the treaty pressed for a more stringent protest against the terms of incorporation. ${ }^{62}$ Wylie was appointed to the Committee for Public Affairs, the Committee for Security and an ad hoc committee for an address. ${ }^{63}$ A letter of 4 November noted that 'its much urged that addressing is a medling of civil affairs' and that 'all our

\footnotetext{
${ }^{55}$ NLS Wodrow MSS Quarto LXXIII, Overtures for religion Jan 1705 by A.F., f. 260.

${ }^{56}$ NRS, Correspondence of the dukes of Hamilton, GD406/1/9747, Robert Wylie to duke of Hamilton, 1 July 1706; NLS Wodrow MSS Quarto XXX, f. 265, 269.

${ }^{57}$ [Robert Wylie], A letter concerning the union ([Edinburgh], 1706).

58 [Robert Wylie], The insecurity of a printed overture for an act for the Church's security ([Edinburgh], [1706]).

59 [Wylie], A letter from a member of the commission, 7-8. See also Raffe, 'Presbyterianism', 331.

${ }^{60}$ NRS Correspondence of the dukes of Hamilton, GD406/1/9747, Robert Wylie to duke of Hamilton, 1 July 1706.

${ }^{61}$ NRS Minutes of the Synod of Glasgow and Ayr, CH2/464/2, 103-105.

62 Bowie, Scottish Public Opinion, 118-119.

${ }^{63}$ NRS Papers of the General Assembly of the Church of Scotland, Main Series, CH1/2/25/2, f. 288; Registers of Acts of the Commission of the General Assembly, $\mathrm{CH} 1 / 3 / 8, \mathrm{ff} .226-72$.
} 
$\mathrm{R}$ [uling] E[Iders] in the Commission' and many clerics are 'for the churches silence', 'but our confession of faith is plain that in cases extraordinary we may petition' ${ }^{64}$

Wylie's papers include a draft address that expressed a willingness to accept a treaty of union on terms that would be 'equal, honourable and safe to this church and nation'. ${ }^{65}$ Other addresses using similar language made clear that only a federal or regnal union in which the Scottish realm and parliament continued to exist could qualify. An address by the Convention of Royal Burghs rejected a union of the kingdoms and parliaments while stating that 'we are not against an honourable and safe union'. ${ }^{66}$ An address in the papers of the Hamilton of Dalziel family, used by ten parishes from the presbyteries of Hamilton and Lanark, stated that 'we are not against ane honourable and safe union with England consisting with the being \& civil Liberties of this ancient Kingdom, ${ }^{67}$ For Steuart of Pardovan, an honourable and safe union meant a confederal union like that of the Dutch provinces, 'by which every Province preserves Its Independency \& Soveraignty', or an 'Entire Union' with full representation for the Scots, either 'the Scots parliament had been erected into a Third house of Parliament' or 'the Entire Scots parliament had imbodyd respectively with the two Houses of the English' parliament. ${ }^{68}$ Other forms of union being mooted outside parliament in early November included an assembly with an equal proportion of members and the maintenance of both parliaments 'with good Regulations and each to have a negative upon the other'. ${ }^{69}$

On 8 November, the enlarged Commission sent a second address to parliament raising specific concerns 'in case this proposed treaty of union shall be concluded' ${ }^{70}$ The address asked the estates to ensure that the English sacramental test not be used to bar Presbyterians from crown office and that an Anglican monarch not impose oaths contrary to Presbyterian principles, including

\footnotetext{
${ }^{64}$ NLS Wodrow MSS Quarto XL, Newsletters, 4 Nov. 1706. The National Library of Scotland has attributed these newsletters to Robert Wodrow because the copy is in Wodrow's hand and the author identified as 'R. W.' Robert Wodrow's letters place him in Edinburgh in November and December, but the content of these letters is not always consistent with other letters known to be written by Wodrow. The letters may have been written by Robert Wylie during his trips to Edinburgh.

${ }^{65}$ NLS Wodrow MSS Quarto LXXIII, Draft address [1706], f. 272.

${ }^{66}$ Lockhart, 'Scotland's Ruine', 151. Derek Patrick has interpreted the addresses as being favourable to 'closer union', but the texts make clear that they mean a form of regal or federal union in which the Scottish parliament, church and realm remained intact. Patrick, 'The Kirk, Parliament and the Union', 100.

${ }^{67}$ North Lanarkshire Council Archives, Motherwell Heritage Centre, USC 052, Hamilton of Dalziel papers. NRS Supplementary parliamentary papers, PA 7/28/50 Avendale, 53 Bothwell, 57 Cambusnethan, 66 Dalserf, 72 [East] Kilbride, 73 Lesmahago, 77 East Monkland, 78 Old Monkland, 81 Shotts, 82 Stonehouse.

${ }^{68}$ Steuart of Pardovan, 'A short account', f. 143v. (p. 12). On forms of union, see John Robertson, 'Empire and union: two concepts of the early modern European political order' in Robertson (ed.) A Union for Empire. In 1670, Scottish negotiators had proposed that the Scottish estates be added to the English parliament; Clare Jackson, 'The Anglo-Scottish union negotiations of 1670' in T. Claydon and T. N. Corns, Religion, Culture and National Community in the 1670s (Cardiff, 2011), 36, 52.

${ }^{69}$ NLS Wodrow MSS Quarto XL, Newsletters, 4 Nov. 1706.

${ }^{70}$ Lockhart of Carnwath, 'Scotland's Ruine', 154.
} 
the English abjuration oath. It requested the insertion of a promise to maintain the Scottish church into the British coronation oath and the establishment of a commission to cooperate with the church on administrative and judicial matters, including public fasts. ${ }^{71}$ Lastly, the address protested against the presence of bishops in the proposed British House of Lords as 'contrary to our known principles and covenants' ${ }^{72}$ Though the address did not reject incorporation outright, the minutes of parliament indicate that it was understood as 'representing several difficulties in relation to some of the articles of union and craving suitable remedies'. ${ }^{73}$ Sir John Clerk of Penicuik saw complaints against the English sacramental test as intending to 'frustrate union by imposing tough conditions', because any limitation of the English test would be unacceptable to the English parliament. ${ }^{74}$ To weaken the address, lay elders from the Court coalition presented public protestations in the Commission and parliament to record their dissent. ${ }^{75}$

In response, the synod of Glasgow and Ayr proposed that presbyteries should petition parliament in support of the Commission's address, the elders' protests having made it seem 'but the deed of a pack't club and not the general sense of the church of Scotland'. ${ }^{76}$ This coincided with an addressing campaign coordinated by Country party leaders. ${ }^{77}$ In total, 79 addresses from 116 localities plus an address from the Hebronites (dissenting followers of the clergyman John Hepburn in Galloway) came to parliament between early November and January. ${ }^{78}$ The synod's proposal for presbyterial petitions resulted in petitions from just three presbyteries, Lanark on 18 November and Hamilton on 11 December, and the presbytery of Dunblane in the synod of Perth and Stirling, also on 11 December. ${ }^{79}$ The influence of the synod of Glasgow \& Ayr on Dunblane can be seen in the record of a special meeting held on 3 December noting a sense of 'Duty' to follow the example of the

\footnotetext{
${ }^{71}$ The imposition of fasts by civil authorities without consultation of the church became a significant issue after the Union. Raffe, 'Presbyterianism', 332-4.

72 Lockhart of Carnwath, 'Scotland's Ruine', 153-4.

${ }^{73}$ RPS M1706/10/18, 'Petition of the general assembly read', 8 November 1706.

${ }^{74}$ Sir John Clerk of Penicuik, History of the Union of Scotland and England, trans. and ed. D. Duncan (Edinburgh, 1993), 155. The sensitivity of the abjuration oath issue is indicated by its late inclusion in the address after extensive debate. Patrick, 'The Kirk, Parliament and the Union', 103.

${ }^{75}$ These included the earls of Rothes and Marchmont, Marchmont's son Lord Polwarth, and George Baillie of Jerviswood. Sir John Clerk of Penicuik, History of the Union of Scotland and England, trans. and ed. D. Duncan (Edinburgh, 1993), 119; Bowie, Scottish Public Opinion, 135; Stephen, Scottish Presbyterians, 61.

${ }^{76}$ NLS Wodrow MSS Quarto LXXIII, Overtures (1706), f. 271, Letter to Presbyteries of Paisley and Dumbarton to follow Lanark's lead in addressing (1706), f. 277, Letter (1706), f. 278.

77 Lockhart of Carnwath, 'Scotland's Ruine', 148-50.

${ }^{78}$ NRS Supplementary Parliamentary Papers, PA 7/28/1-83; Karin Bowie, 'Scottish public opinion and the making of the Union of 1707', University of Glasgow PhD thesis (2004), Appendix E. For maps of petitioning localities, see Peter G. B. McNeill and Hector L. MacQueen (eds), An Atlas of Scottish History to 1707 (Edinburgh, 1996), 152-3.

${ }^{79}$ NLS Wodrow MSS Quarto LXXIII, Act of Synod of Glasgow and Ayr, f. 267. NRS Supplementary Parliamentary Papers PA 7/20/28, Presbytery of Lanark, 18 November 1706; PA 7/20/49, Presbytery of Dunblane, 11 December 1706; PA 7/20/50, Presbytery of Hamilton, 11 December 1706. The Hamilton address was signed by Wylie, twelve other clergymen and seven elders.
} 
Commission and 'some presbyteries' to address, 'that nothing be done which may tend to the prejudice of this national Church and the work of Reformation'.$^{80}$

All three presbyterial addresses expressed concurrence with the addresses of the Commission and urged the settlement of the Protestant succession. Hamilton presbytery requested an address to the queen followed by an act of parliament on the succession, while Lanark asked for 'a happy setlement of a protestant Successor under such just and reasonable Limitations or provisions as the circumstances of this kingdom Do necessarily require' ${ }^{81}$ Both Lanark and Hamilton also drew the attention of Parliament to popular discontent in their bounds. This was reinforced by anti-incorporation addresses sent to parliament from 21 parishes in these two presbyteries, accounting for two-thirds of all parish addresses. ${ }^{82}$ Hamilton presbytery's address was felt to be so strongly worded as to require censure, as did a 'scurrilous' tract by Archibald Foyer sentenced on 12 December to be burned by the hangman. ${ }^{83}$ Another clergyman from the presbytery of Lanark, John Bannatyne of Lanark parish, described by Daniel Defoe as a 'firebrand', published robust arguments against incorporation in pamphlet form. ${ }^{84}$ Defoe also singled out Thomas Linning, a former Cameronian minister who came into the Scottish church after the Revolution. Linning signed the address from his parish of Lesmahago in Lanark presbytery.

On 15 November, as parliament considered the second article of the treaty on the Hanoverian succession, the Commission of the General Assembly submitted a third address to parliament warning against the activities of Episcopalian and Catholic Jacobites and urging the settlement of the Protestant succession. This reiterated arguments against toleration made in 1703 suggesting that Episcopalians were 'supported and Encouraged by a party disaffected to the present Establishment, and to the true interests of the Nation both sacred and Civil, from the hopes of a Popish successour to the Crown'. It also included the provocative suggestion that Episcopalian dissenters used the English liturgy 'perhaps to gratify some in a neighbouring Church'. The Commission asked parliament to 'Establish the succession of the Crown in the Protestant lyne, in such a way as may be most effectual for secureing Truth according to our knowen and declared principles, Maintaining of peace in the Nation, and preventing the above Mentioned Evils for the

\footnotetext{
${ }^{80}$ NRS Minutes of the Presbytery of Dunblane, CH2/723/5, 3 December 1706.

${ }^{81}$ NRS Supplementary Parliamentary Papers PA 7/20/28 Lanark, PA 7/20/49 Dunblane, PA 7/20/50 Hamilton.

${ }^{82}$ Bowie, 'Scottish public opinion', Appendix F.

${ }^{83}$ [Archibald Foyer], Queries to the Presbyterian noblemen and gentlemen, barons, burgesses, ministers and commoners in Scotland, who are for the scheme of an incorporating union with England ([Edinburgh], [1706]). RPS 1706/10/141, 'Order: printing to be destroyed', 12 December 1706. On the attribution of this pamphlet, see Bowie, 'Popular resistance and the ratification', 22 n.58.

${ }^{84}$ [John Bannatyne], Some queries proposed to consideration, relative to the union now intended ([Edinburgh], [1706]). George Harris Healey (ed.), The Letters of Daniel Defoe (Oxford, 1955), 152; NRS Supplementary Parliamentary Papers PA 7/28/73 Lesmahago.
} 
future' ${ }^{85}$ This left open the possibility of voting for the Hanoverian succession with limitations rather than incorporating union.

William Johnstone, first marquis of Annandale, followed this with renewed proposals for the ratification of the succession with limitations. When the first article for a united kingdom was debated on 4 November, he had presented a resolve rejecting incorporation and proposing instead either the succession with limitations or a federal union. ${ }^{86}$ According to secretary of state John Erskine, earl of Mar, 'the opposing party's last shift is to be an Act setling the succession with limitations as formerly proposed'. Mar thought that 'Annandale, Duke Hamilton and all his people, ar join'd in this, and that Annandale is to propose it'. ${ }^{87}$ Annandale was said to have advertised his resolve of 4 November in advance, hoping to gather broad support from Presbyterians in parliament. ${ }^{88}$ As predicted by Mar, however, the resolve failed because 'the new party [i.e. the New Party of 1704 or squadrone volante] will stand by [the Court party] for the Union' ${ }^{89}$ According to Steuart of Pardovan, the members of the squadrone were 'rather Political than Religious Whigs' and they had determined 'to stick together, and Render themselves necessary' as a voting bloc. ${ }^{90}$ On 15 November, Annandale tried again, moving that parliament 'proceed to settle the succession upon limitations and regulations'. This was followed with a motion for a recess to formulate an address to the queen to indicate 'the great aversion in many persons to an incorporating union'. ${ }^{91}$ Defoe reported this as intending to 'Accquaint her Majtie what a ferment the Nation was in and how the Matter was Vigorously Opposed by The wholl Country'. ${ }^{92}$ On 18 November, Robert Wodrow commented in a letter from Edinburgh to his father in Glasgow that Annandale's resolve was said to have the support of Lord Treasurer Godolphin and 'Leading Whiggs in England', but that 'our courtiers are resolved to push on this Scheme of the union. ${ }^{93}$ After the failure of Annandale's motion, Earl Marischal William Keith responded to the ratification of the second article on the succession by leading a Country protestation reasserting the terms of the Act of Security for 'conditions of government' on the successor. ${ }^{94}$

\footnotetext{
${ }^{85}$ NRS Supplementary Parliamentary Papers PA 7/20/25, Representation and Petition of the Commission of the General Assembly, 15 November 1706.

${ }^{86}$ RPS M1706/10/15, 'Article of union read and resolve approved', 4 November 1706.

${ }^{87}$ Paton (ed.), Manuscripts of the Earl of Mar, 310-311.

${ }^{88}$ Healey (ed.), Letters of Daniel Defoe, 158.

${ }^{89}$ Paton (ed.), Manuscripts of the Earl of Mar, 311

${ }^{90}$ Steuart of Pardovan, 'A short account', f. 144v (p. 14).

${ }^{91}$ RPS 1706/10/68, 'Procedure: second article read, motions and debate', 15 November 1706; RPS M1706/10/24, 'Article of union and resolve read; resolve for an address to the queen debated', 15 November 1706.

92 Healey (ed.), Letters of Daniel Defoe, 149.

93 NLS Wodrow MSS Letters Quarto IV, Robert Wodrow to James Wodrow, 18/19 November 1706, f. 112. See also Healey (ed.), Letters of Daniel Defoe, 158.

${ }^{94}$ RPS M1706/10/24, 'Protestation for conditions of government of an English successor', 15 November 1706.
} 
With addresses and resolves making little headway in parliament, efforts were made to intimidate parliament with legal armed musters. A burgh and parish militia had been created in 1704 by the Act of Security. ${ }^{95}$ Wylie had been involved in organising the new militia in his parish late in $1704 .{ }^{96}$ Early in November 1706, an overture to the synod of Glasgow and Ayr urged 'that there be frequent rendezvous and exercises of the fencible men through all the Burghs and paroches of this countrey, that in case their service and assistance shall be required for the defence and maintenance of the liberties and rights of the church and Nation, they may be in all suitable readiness to answer the call. ${ }^{97}$ Daniel Defoe reported that ' 13 Ministers of parishes in their severall pulpits' read a paper calling for a rendezvous of the parish militia. ${ }^{98}$ Writing on 28 November, the earl of Mar recorded that 'Mr. Wylie, the minister of Hamilton appointed the people to meet out of the pulpit, and actually met with them at the place appointed, where the other minister of the place [Alexander Findlater, second charge] offered to be their captain. ${ }^{99}$ The duchess of Hamilton wrote to her son the duke on 29 November that she had encouraged 'frequent Rendevouz' in the parishes. ${ }^{100}$

Alongside the mobilisation of the parish militia, Wylie's papers reveal an intention to weaken the government's standing forces by urging troops to use petitions to express their opposition to incorporation and their unwillingness to act against fellow countrymen who were 'according to Law in Arms against it'. ${ }^{101}$ Defoe's letters to London warned that 'some practices have been used to Infect the souldiers'. ${ }^{102}$ Rumours of an intended descent on Edinburgh and reports to parliament of 'tumultuary and irregular meetings of men under armes' with a 'designe of marching to disturb the parliament' allowed the government to pass a proclamation against unauthorised meetings on 29 November and an act suspending the militia clause of the Act of Security on the following day. ${ }^{103}$ Supplementary troops were ordered to the English border and the north of Ireland. ${ }^{104}$

A letter written from Edinburgh to Wylie in Hamilton on 30 November expressed the view that the musters had been 'artfully improven' in parliament to secure the suspension of mustering,

\footnotetext{
${ }^{95}$ RPS 1704/7/68, 'Act for the security of the kingdom', 5 August 1704.

${ }^{96}$ NLS Wodrow MSS Quarto LXXIII, Proposals on the militia (1704), f. 259.

${ }^{97}$ NLS Wodrow MSS Quarto LXXIII, Overtures (1706), f. 271. The overtures are undated but internal evidence suggests they were written shortly after the 8 November address of the Commission.

${ }_{98}$ Healey (ed.), Letters of Daniel Defoe, 165. These probably were the ministers of Hamilton presbytery.

${ }^{99}$ Scott (ed.), Fasti, iii, 260; Paton (ed.), Manuscripts of the Earl of Mar, 337.

100 NRS Correspondence of the dukes of Hamilton, GD 406/1/9734, duchess of Hamilton to duke of Hamilton, 29 November 1706.

${ }^{101}$ NLS Wodrow MSS Quarto LXXIII, Proposals for orchestrating anti-Union petitioning from the army with a form of petition, f. 281.

102 Healey (ed.), Letters of Daniel Defoe, 143.

103 Healey (ed.), Letters of Daniel Defoe, 150; RPS 1706/1/105, 'Procedure: reports of unlawful gatherings and debate thereon', 29 November 1706; RPS 1706/10/108, 'Proclamation against unlawful convocations', 29 November 1706; RPS 1706/10/112, 'Act against all musters and rendezvous', 30 November 1706. ${ }^{104}$ Clerk of Penicuik, History, 103; Paton (ed.), Manuscripts of the Earl of Mar, 335, 338, 340.
} 
dismissing stories of 'a great muster' and invitations to march to Edinburgh as 'absurd' 105 Nevertheless, plans for more than a muster are described in the papers of Major James Cunningham of Aiket in Ayrshire, a Presbyterian laird and former army officer, and the memoirs of George Lockhart of Carnwath. Cunningham led Lockhart to believe that he would lead a rising of Presbyterians from the southwest in late November. Lockhart hoped that this would lead to a restoration of the Stuarts with the aid of armed men from Perthshire raised by the duke of Atholl. Both the Whiggamore Raid of 1649 and the appearance of armed Presbyterians in Edinburgh during the 1689 Revolution provided precedents for such an action. ${ }^{106}$ Lockhart believed that the venture collapsed when the duke of Hamilton withdrew his support, but did not know that Major Cunningham was working as a double agent for the duke of Queensberry. ${ }^{107}$ As has been shown, Cunningham later revealed that he acted to prevent an English conquest in the event of a Presbyterian rising. ${ }^{108}$

Less dangerous opposition was considered by the Country opposition in the form of a formal protestation against the treaty followed by a withdrawal of members. This would have emulated a protestation and walkout made by the duke of Hamilton and his followers in the 1702 session. ${ }^{109}$ On 29 October before the voting on the articles began, Defoe reported that the opposition planned to 'Protest' and 'leav the House' if they could not defeat the articles. ${ }^{110}$ According to Steuart of Pardovan, the success of the first articles led 'Severall Judicious members, and others, against this Union' to 'Think, that the only way to prevent it's being a Concluded Treaty; was, for those members who were against it, to signifie so much in the House, by a Solemn Protestation, and then unanimously withdraw. ${ }^{111}$ Wylie thought that the queen's managers could be forced to 'leave off the union' with a protestation that the treaty contradicted the 'declared mind, Institutions and Interest' of the nation, followed by a 'national Addresse to the Queen, representing the true state \& mind of the nation' and asking for new elections for a parliament 'instructed with the true sense of the nation'. ${ }^{112}$ As an alternative, Wylie proposed that those who had signed addresses from shires,

\footnotetext{
${ }^{105}$ NLS Wodrow Quarto LXXIII, Anon. to Robert Wylie in Hamilton, 30 November 1706, f.282.

${ }^{106}$ William Ferguson, 'The making of the treaty of Union of 1707', Scottish Historical Review XLIII:136 (October 1964), 109; Tim Harris, Revolution: The Great Crisis of the British Monarchy, 1685-1720 (London, 2006), 364421.

${ }^{107}$ Lockhart of Carnwath, 'Scotland's Ruine', 179-84. Defoe also believed a rising to be likely and sent an agent to Galloway to convince the followers of John Hepburn not to march to Edinburgh; Healey (ed.), Letters of Daniel Defoe, 180-1.

${ }^{108}$ NLS Wodrow MSS Quarto LXXII, Major [James] Cunningham [of Aiket], 'Major Cunningham's sentiments of the union with ane account of the motives that induced him to be for it', f. 264v-270; Bowie, 'Popular resistance and the ratification', 16-17.

${ }^{109}$ Lockhart of Carnwath, 'Scotland's Ruine', 12-14.

${ }^{110}$ Healey (ed.), Letters of Daniel Defoe, 137.

${ }^{111}$ Steuart of Pardovan, 'A short account', f. 142 (p. 9).

${ }^{112}$ NLS Wodrow MSS Quarto LXXIII, Proposals (Nov. 1706), f. 276.
} 
burghs and parishes should gather 'in a body together' to 'demand an answer from parliament to their severall addresses'. Both tactics were designed to be 'peaceable, legal and safe'. ${ }^{113}$ In midDecember, the duke of Atholl began to organise a gathering of addressers in Edinburgh, aided by the duchess of Hamilton, Andrew Fletcher of Saltoun and Atholl's associates in the Jacobite wing of the Country party. An address to the queen was drafted, demanding new elections and a meeting of the General Assembly. The duke of Hamilton, however, delayed matters by insisting that the address ask for the succession with limitations as an alternative to incorporation. The disagreement gave the government time to disrupt the plan by proclaiming on 27 December that any unauthorised gatherings would be considered seditious. ${ }^{114}$

A final stand was made on 7 January, as parliament moved towards a vote on article 22 on the representation of Scotland in the British parliament. ${ }^{115}$ The duke of Atholl delivered a lengthy protestation against incorporation as a forfeiting of the estates' rights of representation. Citing 'a generall dislike' for the treaty, he demanded that the queen be advised of the 'inclinations of her people' so that she could call new elections. ${ }^{116}$ Protestations also were made by the earls of Buchan, Erroll, Marischal and Abercorn, George Lockhart of Carnwath and Walter Steuart of Pardovan. ${ }^{117}$ The duke of Hamilton and marquis of Annandale had planned to propose the succession, followed by a protestation and withdrawal designed to 'startle the English'. Annandale supplied a lengthy protestation stating that incorporation was unacceptable to the nation and that any legislation passed by the British parliament would be considered illegitimate. ${ }^{118}$ Hamilton managed to convince the Cavaliers to join in the protest by arguing that adherence to the protestation did not entail acceptance of the succession. According to Lockhart, the duke of Atholl did not intend to endorse Hamilton's protest but agreed to leave parliament with him. The walkout collapsed when Hamilton succumbed to strong pressure from Court managers and refused to make his protestation. ${ }^{119}$

Lockhart felt that the opposition had missed its last real chance. He reported that chancellor James Ogilvie, first earl of Seafield, had told him that 'if the measure had been pursued and executed the Commissioner and other ministers of state had resolved to prorogue the Parliament

\footnotetext{
${ }^{113}$ NLS Wodrow MSS Quarto LXXIII, Proposals (Nov. 1706), f. 276. See also the call for a gathering of petitioners in Queries to the Presbyterian noblemen and gentlemen, barons, burgesses, ministers and commons in Scotland ([1706]).

${ }^{114}$ Lockhart of Carnwath, 'Scotland's Ruine', 184-8; RPS 1706/10/176, 'A proclamation discharging unwarrantable and seditious convocations and meetings', 27 December 1706; Bowie, 'Popular resistance and the ratification', 22-24; Bowie, 'Popular resistance, religion and the Union of 1707', 49-50.

${ }^{115}$ Article 22 was first read on 6 January and voted on 9 January 1707. RPS M1706/10/73-79.

${ }^{116}$ RPS 1706/10/212, 'Protestation by the duke of Atholl', 7 January 1707.

${ }^{117}$ RPS M1706/10/76, 'Article of union read and protestations against', 7 January 1707; RPS 1706/10/213-218, Protestations, 7 January 1707; Lockhart of Carnwath, 'Scotland's Ruine', 197-202.

${ }^{118}$ Lockhart reported his belief that the text was written by the Lord Advocate Sir James Steuart of Goodtrees. Lockhart of Carnwath, 'Scotland's Ruine', 189.

${ }^{119}$ Lockhart of Carnwath, 'Scotland's Ruine', 188-96.
} 
and give over the prosecution of the union'. ${ }^{120}$ In his memoirs, Clerk of Penicuik highlighted the Court party's fear of a forced dissolution of parliament. ${ }^{121}$ Vigorous opposition from Hamilton's Country party had pushed Queensberry to a precipitate ending of the May 1700 parliamentary session and Steuart of Pardovan expressed the view that an adjournment might have been possible in November given Queensberry's 'natural meekness' and his 'being also much intimidate, and ashamed' by the personal abuse aimed at him by Edinburgh crowds. ${ }^{122}$ The delaying of the walkout to January allowed Queensberry's determination to be strengthened by his associates, especially the earl of Stair and the duke of Argyll, while Hamilton's was weakened. ${ }^{123}$

In the manifesto below, the settlement of the succession is proposed as the outcome of armed action which seems designed to take place before the events of 7 January. On 2 December, after musters had been cancelled and troops moved to the borders, a letter-writer maintained a hope that 'the appearance of the country' in arms might stop the treaty 'by force'. ${ }^{124}$ Rather than 'silently submit to eternall slavery', the letter proposed that a 'manifesto' be 'spread throu the nation' to call supporters to Edinburgh before the final ratification of the treaty. It reported that the duke of Hamilton wanted the manifesto to propose the settlement of the succession. Hamilton was not prepared to support armed action and the writer did not trust Atholl's Jacobite followers but was hopeful that the two dukes might take charge once the insurgents were in the field. ${ }^{125}$

The manifesto below seems to have been drafted as envisaged by this letter. It justifies an armed descent on Edinburgh as an unwanted but necessary last resort to prevent the ratification of the union treaty. It demands that the queen be informed of the nation's opposition to a union that is not 'honourable, advantageous and safe' and claims a national willingness to accept the Hanoverian succession with 'such conditions and provisions as a free parliament shall judge necessary to deliver this nation from English Influence and to secure our civil Rights and liberties, the Independency and soveraignity of the nation, and the presbyterian Government of the church as founded upon the claim of Right and established by Law'. It calls for elections to replace pro-union voters and pensioners in the parliament and form 'a true loyal Scots parliament'. It politely suggests that Queensberry should continue in his post until he can be replaced and promises that no harm will come to those who accept the intended turn of events.

\footnotetext{
${ }^{120}$ Lockhart of Carnwath, 'Scotland's Ruine', 196.

${ }^{121}$ Clerk of Penicuik, History, 99, 152.

${ }^{122}$ Steuart of Pardovan, 'A short account', f. 142 (p. 9). Queensberry's biographer has taken a more positive view of the duke's confidence in the 1706-07 session: Mackay, The Duke of Queensberry, 212-13.

${ }^{123}$ Steuart of Pardovan, 'A short account', f. 142 (p. 9); Bowie, Scottish Public Opinion, 31.

${ }^{124}$ NLS Wodrow MSS Quarto XL, Newsletters, 2 December 1706. As noted above, this letter may have been written by Wylie. The content of the letter does not fit with Robert Wodrow's statement in late November that there is 'noe feasibility of any appearance' by Presbyterians because of the proximity of government troops (NLS, Wodrow Letters Quarto IV, letter 80, 28 Nov. 1706, f. 119v).

${ }^{125}$ NLS Wodrow MSS Quarto XL, Newsletters, 2 December 1706.
} 
Though the manifesto speaks in terms of the nation, its aims and arguments have a clear Presbyterian slant consistent with those of Wylie and other Presbyterian pamphleteers and addressers. It expresses a range of religious, constitutional, economic and political objections to the union, including the threat posed by an English parliamentary majority to Scotland's church and interests, the destructive effect of higher taxes, the dubious benefits of free trade and the shameful loss of Scotland's ancient sovereignty. These arguments closely resemble those of the petition of the Convention of Royal Burghs, whose text was supplied by Lt. Col. John Erskine of Carnock, provost of Stirling and ruling elder for the Presbytery of Dunfermline in the 1706 General Assembly. ${ }^{126}$ Erskine of Carnock combined mustering and petitioning by calling out the Stirling militia to sign an address from the burgh against incorporation, producing one of the largest local petitions with over 560 signatures, headed by his own. ${ }^{127}$ In economic terms, the manifesto echoes the Convention's address in arguing that incorporation would bring 'unsupportable Impositions and Burdens' and the 'fraudulent \& deceitful pretence' of free trade would only impoverish Scotland. As Christopher Whatley has shown, the extension of English customs and excise rates to Scotland in a British trading area threatened negative consequences through higher duties and a loss of protective tariffs. Fierce opposition led to the negotiation of concessions known as the 'Explanations'. ${ }^{128}$ Though a 'communication of trade' had been advocated by the Country party since 1703, James Hodges had argued that 'all the Sugar of the English Plantations' could not 'sweeten' an incorporating union. ${ }^{129}$ In his 1706 Insecurity of a printed overture, Wylie expressed doubt about the potential benefits of the promised free trade under higher trading duties. ${ }^{130}$ The manifesto also notes that the Company of Scotland would be lost along with the rest of Scotland's rights, offices and liberties. Though the Company was by this point nearly defunct, supporters argued that it should not be wound up. ${ }^{131}$ Politically, like the Convention, the manifesto warns against the vulnerability of Scottish interests in a British parliament, a common theme found also in Wylie's tract on the security of the church. A contemporary letter asked 'whither we can have any solid security' given 'the plainly Interfering

\footnotetext{
${ }^{126}$ Lockhart of Carnwath, 'Scotland's Ruine', 151-153; Records of the Convention of Royal Burghs, 5 vols (Edinburgh, 1866-85), iv, 399-400; NRS General Assembly Papers, Main Series, CH1/2/25/1, 13 Feb 1706.

${ }^{127}$ Healey (ed.), Letters of Daniel Defoe, 153; NRS Supplementary Parliamentary Papers PA7/28/48, Stirling. A burning of the articles of union also occurred in Stirling in early December with the support of some town officers. Paton (ed.), Manuscripts of the earls of Mar, 348, 353.

${ }^{128}$ Christopher A. Whatley, 'Economic Causes and Consequences of the Union of 1707: A Survey', Scottish Historical Review 68, 2:186 (1989), 150-81.

${ }^{129}$ [James Hodges], The rights and interests of the two British monarchies, inquir'd into, and clear'd; with a special respect to an united or separate state (London, 1703), 22.

${ }^{130}$ Wylie, Insecurity of a printed overture, 5-6.

${ }^{131}$ The humble representation of the Council-General of the Company of Scotland Trading to Africa and the Indies (1706); Andrew Mackillop, 'A Union for Empire? Scotland, the English East India Company and the British Union' SHR 87 (2008 supplement), 116-34; Douglas Watt, The Price of Scotland (Edinburgh, 2007), 23031.
} 
Interests of North and South Britain, as to Religion or Trade' and 'whither we can trust England, or not, when they have the Balance both of vote and pouer' in the united parliament. ${ }^{132}$

In addition, like the Commission's second address, the manifesto objects to a united parliament that included 'prelats and men prelatically affected'. It argues that incorporation would lead the Scots to commit national perjury in their disregard for their 'sacred engagement of most solemn covenants' and would endanger Scotland's 'covenanted work of Reformation'. The presbytery of Lanark also stated that incorporating union would be 'Contrarie To our known principles and Covenants' and many parish addresses argued that incorporation would betray Scotland's covenanted reformation. ${ }^{133}$ For these Presbyterians, the 1638 and 1643 covenants required the Scots to maintain not just Presbyterian government and worship but also the realm and parliament of Scotland. As James Hodges put it, 'an incorporating union with England is Absolutely Inconsistent with the Adhering to the Obligation of that National Oath'. ${ }^{134}$ Echoing Wylie's 1703 arguments against toleration, the manifesto anticipated that incorporation would lead to toleration for Episcopalian dissent, the erosion of the discipline and purity of the Kirk and 'the utter subversion of the present legal settlement by presbitery'. ${ }^{135}$

The manifesto accuses the treaty negotiators of treason in agreeing to unmake the kingdom. In parliament, Andrew Fletcher of Saltoun had accused the 'treaters' of being 'traitors' and the insult had spread in the streets. ${ }^{136}$ An act of 1703 made it treason to undermine the 1689 Claim of Right and, by extension, the post-Revolution Scottish monarchy, parliament and church regulated by its terms. ${ }^{137}$ In keeping with Country complaints, the manifesto characterises the Court coalition as an unrepresentative 'Faction' in thrall to English interests, bent on forcing the treaty through parliament in defiance of the wishes of the nation. It excoriates parliament for ignoring the 'dissatisfaction \& aversation' communicated by dozens of addresses and insists that the treaty should be thrown out as being 'not only without the consent but contrary to the publickly expressed mind of the nation'.

In making these demands, the manifesto speaks in the name of 'the free people of Scotland'. This unusually populist rhetoric allowed Wylie to invoke the subjects of the realm of Scotland as a

\footnotetext{
${ }^{132}$ NLS, Wodrow Quarto XL, Newsletters, 27 December 1706. As noted above, this may have been written by Wylie.

${ }^{133}$ See the group of parishes from Hamilton and Lanark presbytery noted above.

${ }^{134}$ [James Hodges], The rights and interests of the two British monarchies, with a special respect to an united or separate state (London, 1706), 58.

${ }^{135}$ Wylie, Insecurity of a printed overture; [James Webster], Lawful prejudices against an incorporating union with England (Edinburgh, 1707).

${ }^{136}$ Steuart of Pardovan, 'A short account', f. 141 (p. 7); P. H. Scott, Andrew Fletcher and the Treaty of Union, (Edinburgh, 1994), 186.

${ }^{137}$ RPS 1703/5/190, 'Act ratifieing the turning the meeting of the estates in the year 1689 into a parliament', 16 Sept. 1703.
} 
body whose collective opinion could be contrasted to that of the estates in parliament. The 'people' might be interpreted in narrow terms as a body of electors, especially as the manifesto refers to the views of 'constituents'. Yet most addresses from burghs and shires included ordinary freeholders, burgesses and inhabitants alongside crown proprietors and burgh councils. ${ }^{138}$ The national address prepared by the duke of Athol was to have been signed by a general body of 'noblemen, barons, gentlemen, burgesses and other subscribers' ${ }^{139}$ The intended social breadth of Wylie's gathered 'people' is also suggested by the militia, composed of Protestant fencible men aged 16 to $60 .{ }^{140}$

Wylie's emphasis on a 'free' people indicates the importance of freedom from monarchical tyranny, Court management and English hegemony. The manifesto states that ever since the Revolution, the 'free people' of Scotland had hoped to reform their constitution to reduce 'arbitrary principles', indicating the constitutionalist efforts of the reformist Club in 1689-90 and the campaign for limitations on the successor pursued from $1703 .{ }^{141}$ The 1689 Claim of Right had asserted that Scotland enjoyed a 'legal limited monarchy' in which the king governed according to law. ${ }^{142}$ The government's proclamations against unauthorised meetings were later characterised by Steuart of Pardovan as a betrayal of 'the Liberty \& priviledge of the free subjects of this Realm. ${ }^{143}$ Though recent pamphlets had revived claims for England's historic suzerainty over Scotland, the manifesto speaks in terms of a 'free people' and 'Ancient free kingdom' and condemns English encroachment on the rights of the people of Scotland in terms similar to the denunciation of English hegemony in the Union of Crowns by Andrew Fletcher of Saltoun and other Country voices. ${ }^{144}$ In his memoirs, George Lockhart of Carnwath posed the question of whether Scotland would 'remain free and independent' or become subject to English rule, unable to 'defend its own liberties as became a free people'. ${ }^{145}$ The manifesto adopts the famous closing lines on liberty from the 1320 Declaration of Arbroath: 'So long as an hundred Scotsmen remain alive, we will never be subjected any manner of way to the dominion of England. It is not for Glory, Riches and honours we fight; but for liberty,

\footnotetext{
${ }^{138}$ The Scottish electorate was based on property held of the crown. The shire electorate comprised barons, freeholders and feuars of substantial estates held of the crown. In the royal burghs, selection had become oligarchic with the town council choosing its representative. See Keith M. Brown, 'The Second Estate: Parliament and the Nobility' and Alan R. Macdonald, 'The Third Estate: Parliament and the Burghs' in Parliament in Context, 1235-1707, ed. K. M. Brown and A. R. Macdonald (Edinburgh, 2010).

${ }^{139}$ Lockhart of Carnwath, 'Scotland's Ruine', 185.

${ }^{140}$ Electors, addressers and fencibles were always male, though the pamphleteer James Hodges made the striking suggestion that an assembly of male and female freeholders should be called to vote directly on the treaty. [Hodges], Rights and interests (1706), 71, 74.

${ }^{141}$ James Halliday, 'The Club and the Revolution in Scotland 1689-90', SHR 45:140, 2 (Oct. 1966), 143-159.

${ }^{142}$ RPS 1689/3/108, 'Declaration of the estates containing the Claim of Right and the offer of the crown to the king and queen of England', 11 April 1689

${ }^{143}$ Steuart of Pardovan, 'A short account', f. 149v (p. 24).

${ }^{144}$ William Ferguson, 'Imperial Crowns: A Neglected Facet of the Background on the Treaty of Union of 1707', SHR 53:155, 1 (1974), 22-44.

${ }^{145}$ Lockhart, 'Scotland's Ruine', 141.
} 
which no good man loseth but with his life.' As Ted Cowan has shown, the Declaration survived in a handful of chronicles and was translated from Latin by Sir George Mackenzie of Rosehaugh in 1680. It was printed at the 1689 Revolution and in 1705 and 1706. Its appearance in this manifesto suggests that the text was starting to attain what Cowan has called its 'parahistorical' symbolic status. ${ }^{146}$ The Declaration provided a shared reservoir of patriotic resources for Presbyterians and Jacobites alike. As Christopher Whatley has shown, the duke of Atholl referenced the same lines in a speech early in November, asserting that 'so long as there were 100 Scots alive "we will not enter into a treaty so dishonourable and entirely subversive"'. ${ }^{147}$ A similar invocation of the Wars of Independence can be seen in the political poetry of the Jacobite William Forbes of Disblair. In Forbes' 1704 poem 'The True Scots Genius, Reviving', a martial, blood-stained female figure of Scotia demanded that Scots parliamentarians follow the example of their heroic ancestors in defending Scotland's freedom from English imperialism. ${ }^{148}$ Forbes' 1705 poem A Pill for Pork Eaters condemned the Union of Crowns as 'fatal Slav'ry' and wished for a 'new Bannockburn' to liberate Scotland. ${ }^{149}$

Despite its patriotic rhetoric, for some contemporaries Wylie's plan would have seemed a dangerously populist purging of elected representatives by an extra-parliamentary force claiming to represent the people. This, combined with the risk that the Jacobites might take over the rising or that English troops might advance into Scotland and treat participants as 'open rebells', helps to explain why this manifesto does not seem to have moved beyond the rough draft stage. ${ }^{150}$ In late December, Defoe could observe wryly that those attempting to collect petitioners for a national address 'do not Deny that if the people had taken that Occasion to have Risen, they would not have been displeased, nor I suppose backwards to Encourage them all they Could. But I do not find they were Very forward to Venture their Own heads in the Fray. ${ }^{151}$

\footnotetext{
${ }^{146}$ Edward J. [Ted] Cowan, 'For Freedom Alone': The Declaration of Arbroath, 1320 (East Linton, 2003), 88-109; Letter in 1320 to Pope John declaring for Robert the Bruce ([Edinburgh], [1706]).

${ }^{147}$ Whatley, The Scots and the Union, 297.

${ }^{148}$ [William Forbes of Disblair], The true Scots genius, reviving ([Edinburgh], 1704). On female representations of Scotland, see also [James Clark, minister of Tron Church, Glasgow?], Scotland's Speech to her Sons ([Edinburgh?, 1706]); [John Hamilton, Lord Belhaven], The Lord Beilhaven's Speech in Parliament the Second Day of November 1706, ([Edinburgh, 1706]), 3 and [William Wright], The comical history of the marriage betwixt Fergusia and Heptarchus ([Edinburgh], 1706). Whatley, Scots and the Union, 205, 289, plate 2; Michael Lynch, 'A nation born again? Scottish identity in the sixteenth and seventeenth centuries' in D. Broun, R. J. Finlay and M. Lynch (eds.), Image and Identity: The Making and Remaking of Scotland through the Ages, (Edinburgh, 1998); Rosalind Carr, 'Gender, National Identity and Political Agency in Eighteenth-Century Scotland', University of Glasgow PhD thesis (2008), 47-49, 63-67.

149 [William Forbes of Disblair], A Pill for Pork Eaters, or a Scots Lancet for an English Swelling ([Edinburgh], 1705), $5,6$.

${ }^{150}$ RPS 'Proclamation against unlawful convocations', 1706/10/108, 29 November 1706.

${ }^{151}$ Healey (ed.), Letters of Daniel Defoe, 188.
} 
Nevertheless, Wylie's draft manifesto is valuable in three main respects. Firstly, it indicates typical Country Presbyterian arguments against incorporation as found in other addresses and pamphlets, confirming recent research on Presbyterian attitudes towards incorporation. Secondly, it demonstrates the extremes measures one clergyman was prepared to consider as part of a range of activities designed to affect parliamentary proceedings. Though the Commission of the General Assembly discouraged resistance by lower church courts and the laity, Wylie and others in the church took steps to defend what they saw as the interests of the church and nation. Wylie's writings indicate the breadth of his intellectual engagement and his intended influence. He and likeminded clergy and elders pressed the Commission towards more assertive addressing and encouraged presbyteries to second these addresses. At the local level, clergy and elders were involved in local mustering and civil addressing in shires, burghs and parishes. ${ }^{152}$ Though organised resistance within the church was concentrated in central and western areas and should not be exaggerated, figures like Wylie contributed to the potential strength of the opposition by coordinating activity between the civil and ecclesiastical spheres.

Thirdly, the document points to the continuing tactical significance of the Hanoverian succession with limitations as an alternative to incorporation. Historians have tended to follow James Hodges in framing the debate as a choice between two forms of union, incorporating or federal. Yet the 1703 pamphlet in which Hodges posed a stark choice between federal and incorporating union predated the Act of Security and was designed to contrast a negative view of incorporation with an attractively vague concept of federal union. ${ }^{153}$ Hodges remained aloof from the settlement of the succession, calling limitations a 'strange Fancy' in $1706 .{ }^{154}$ The Alien Act, however, demanded that the Scots either accept the succession or authorise treaty negotiations and both options were recommended in the queen's letter to parliament in $1705 .{ }^{155}$ Though various forms of union were being discussed outside parliament in 1706, the succession remained the most immediate alternative in practical terms, being achievable with a unilateral act of parliament rather than fresh negotiations. Before the session opened, Wylie believed that a Presbyterian majority could be marshalled for a succession act. Multiple resolves and addresses promoted the succession in hopes of shaking the Court's coalition. Within the opposition, some Jacobite sympathisers were willing to cooperate far enough to defeat the union. Having met with the exiled Stuart queen late in 1701 to discuss the return of James Stuart to a conditional monarchy, John Hamilton, Lord Belhaven joined the duke of Hamilton in seconding Annandale's resolve on 15 November 1706, arguing 'I think

\footnotetext{
${ }^{152}$ Addresses were organised by proprietors in parishes, not kirk sessions, but some parish, shire and burgh addresses include signatures of individuals identifying themselves as clergymen or church elders.

${ }^{153}$ [Hodges], Rights and interests (1703), 2-3; Robertson, 'An Elusive Sovereignty', 206-07.

${ }^{154}$ [Hodges], Rights and interests (1706), 59.

${ }^{155}$ RPS 1705/6/16, 'Her majesty's letter to the parliament', 3 July 1705
} 
it is the best that We can make of it at this time, the fittest measure to prevent Civil Wars, allay the Ferment of the Nation, and far preferable to this Incorporating Union' ${ }^{156}$ Other Cavaliers like Atholl, however, were more reluctant to endorse the succession. In a pamphlet, the Jacobite Patrick Abercrombie argued that the treaty should be rejected, the succession left open and limitations voted as required by the Act of Security. ${ }^{157}$ In drafting his manifesto, Wylie recognised that resolves in favour of the succession would not attract a majority and more assertive action had to be contemplated.

The following transcript retains original spelling and capitalisation. Manuscript contractions have been expanded silently while abbreviated words have been completed in brackets. The draft contains a number of marginal additions in cramped and faint handwriting. These have been incorporated into the text where indicated by the author. Crossed-out sections have not been included except in one case where the sense of the line would have been lost. Where the handwriting has been difficult to decipher, possible readings have been provided with cautions expressed in footnotes. ${ }^{158}$ Explanatory notes provide context on points not already discussed above.

National Library of Scotland, Wodrow Manuscripts, Quarto LXXIII, ff. 283-285

It having pleased the Almighty God of his infinite mercy, by the late glorious Revolution, to which the Just endeavours of the country were not inserviceable to rescue this kingdom from the encroachings of popery and Arbitrary power, and to assert and establish the true liberties of church and state by a claim of Right and sundry good laws and Acts of parliament made in prosecution thereof, Tho our Rights as a free people have since that tyme in divers instances been invaded by the evil counsels \& restles practices of a Faction in Scotland corrupted with arbitrary principles and pensions and english Influence ${ }^{159}$ yet we have hitherto contained ourselves within the bounds of quiet submission and

\footnotetext{
${ }^{156}$ Daniel Szechi, Britain's Lost Revolution? Jacobite Scotland and French Grand Strategy, 1701-8 (Manchester, 2015), 117; [John Hamilton, Lord Belhaven], Lord Beilhaven's Speech in Parliament (Edinburgh, 1706), 82.

${ }^{157}$ [Patrick Abercromby], The advantages of the Act of Security, compar'd with these of the intended union ([Edinburgh], 1707). Daniel Szechi has emphasised the appeal of limitations to the Jacobites as they intended to form a conditional monarchy to regulate a restored Catholic Stuart monarch. Szechi, Britain's Lost Revolution?, 122-23, 125-35.

${ }^{158}$ I am deeply grateful to my colleague Dr. Lionel Glassey for advice on the transcription of this document.

${ }^{159}$ The problem of pensioners in parliament was discussed in the 1704 and 1705 parliaments in relation to a proposed 1704 act for free voting and the 1705 triennial act. Young, 'Scottish parliament', 246-48. The
} 
patience waiting till God in his providence should inspire and direct our Rulers and parliaments unto such measures as should rectify and settle our constitution, and perfect and secure what had been begun in the forsaid happy Revolution, and whereby this nation might be delivered from the pernicious and blasting Influence of an English Court, under which it hath withered and groaned these hundred years past since the joining of the 2 crowns. ${ }^{160}$ But the Treachery and Impudence of that Faction being now come to such an height as to attempt to suppress the Ancient Monarchy[,] extinguish the parliament[,] dissolve the Government of this Nation, and surrender the crown, Rights and priviledges of the nation unto England, ${ }^{161}$ under the Form of a Treaty of union between the commissioners for the 2 kingdoms and having so far prevailed as in despight of all Law, Reason, honour and conscience to draw many others into the same Infatuation and conspiracy with themselves[,] We the free people of Scotland cannot but look upon ourselves as called of God and obliged under the most sacred Bonds ${ }^{162}$ to appear for the relief of our betrayed and sinking country and to use our utmost Endeavors, committing ourselves and our Righteous cause to God the patron, protector \& avenger of the oppressed, for putting a stop to the proceedings of these Betrayers.

who have presumed without any warrant from the parliament and against the known mind of the nation their constituents from their own forethought wickednes \& contrived malice, to go into such a Treaty of Incorporation with England as ruines \& destroyes not only the liberties but the very Being of this Ancient kingdom which God hath preserved by many wonderful providences as a distinct kingdom for near 2000 years. ${ }^{163}$

who have never claimed in their Treaty the Just Rights \& priviledges due unto the subjects of this Kingdom by vertue of their being united in Alledgiance with the subjects of England, nor any Reparation of the many \& great Injuries they have sustained from the English since the devolution of that crown upon their native Soveraign. ${ }^{164}$

reference to 'arbitrary principles' reflects the perception that the Court party favoured the royal prerogative. George Ridpath aimed his 1703 Historical Account of the Antient Rights and Power of the Parliament of Scotland at those in a younger generation who were 'Asserters of Prerogative' (p. 75).

${ }^{160}$ This critique of the Union of Crowns was typical of Country discourse in the decade before the Union. See [George Ridpath] Scotland's grievances relating to Darien, \&c. humbly offered to the consideration of the Parliament ([Edinburgh], 1700) and Fletcher, Political Works, 38, 132-134.

${ }^{161}$ This language of suppression and extinction is used by other addressers including the Convention of Royal Burghs and the group of parish addresses from Hamilton presbytery, discussed above. The template for this group reads 'overturns the very constitutione of this Ancient Kingdom suppresses our Monarchie extinguishes our parliament subjects all our foundamental Rights overthrows our Religion \& Liberty distroys the government of our Church and the puritie of the Gospell'.

${ }_{162}$ This can be read as a reference to the National Covenant of 1638 and Solemn League and Covenant of 1643.

${ }^{163}$ This statement of national distinctiveness in a 2000 year old monarchy is found in many of the addresses against the union sent to the Scottish parliament and some pamphlets. See the Country party address template in Lockhart, 'Scotland's Ruine', 149 and also Bowie, Scottish Public Opinion, 97.

${ }^{164}$ The Presbyterian pamphleteers George Ridpath and James Hodges both argued that the Scots could claim additional rights in the existing Union of Crowns, in particular that the English Navigation Acts should not apply to the Scots as post-nati subjects of the king of England. [George Ridpath], The case of Scots-men residing in 
who have calculated and accommodated their Treaty in all the Articles thereof to the national Interests of England without any regard to those of Scotland, subjecting this Land to unsupportable Impositions and Burdens, and setting it in a way of being utterly impoverished under a fraudulent $\&$ deceitful pretence of a free communication of Trade. ${ }^{165}$

who under the false name of uniting 2 kingdoms have projected the overthrow and perpetual dissolution of the one, adapting all the concerns thereof, and resigning the direction, management $\&$ determination of its whole affairs in a full surrender unto the other which stands intire \& compleat in every part without any the least change or diminution, but is on the contrary strengthned \& confirmed in jurisdiction and power by the servile adjection of the given up \& demolished kingdom. ${ }^{166}$

who under the name of uniting the parliaments have treasonably attempted to abolish that of Scotland to the depriving of this nation of all honour \& safety and of all security for any Reserved Interest whether ecclesiastical or civil; and to the extinguishing of heretable offices, dignity of peerage Rights and priviledges of shyres \& Royal Burrows of being represented in parliament and all other Rights of property that are pretended to be reserved, particularly the dissolving against all law \& justice of the African \& Indian Company the best founded and noblest constitution of any trading society in Europe.

who have endeavoured to impose upon this nation in a most ignominious manner as an Article of their Treaty the Successour of England, nominated by them without any consent of or communication with this free kingdom, and upon the provisions \& conditions framed by the English Acts of parliament for the securing of their own civil \& ecclesiastical constitution without any regard to that of Scotland. ${ }^{167}$

England and in the English plantations (London, 1702); [James Hodges], Essay upon the union. Shewing that the subjects of both nations have been, by the union of the two crowns, justly entitled to all manner of privileges, which the ensuing treaty can give them (London and Edinburgh, 1706). Similar arguments were made in parliamentary speeches, e.g. Whately, The Scots and the Union, 297. On the Navigation Acts and status of Scots in England and its colonies, see Macinnes, Union and Empire, 63, 81-83, 143.

${ }^{165}$ See above for the discussion of doubts about free trade in an incorporating union.

${ }^{166}$ This reflects James Hodges' influential view of incorporation as a virtual conquest, published in his 1703 Rights and interests tract.

${ }^{167}$ This refers to the 1701 Act of Settlement which named the electress Sophia of Hanover as the heir to the English throne and required successive monarchs to be members of the Church of England. This act presumed that the English successor would still be monarch of Scotland, causing great offence in Scotland. As noted above, the Commission of the General Assembly's second petition to parliament asked for specific limitations on future British monarchs including that they be required to swear to maintain the Scottish national church in their coronation oath. 'William III, 1700 \& 1701: An Act for the further Limitation of the Crown and better securing the Rights and Liberties of the Subject [Chapter II. Rot. Parl. 12 \& 13 Gul. III. p. 1. n. 2.]', Statutes of the Realm: volume 7: 1695-1701 (1820), pp. 636-638, http://www.british-history.ac.uk (accessed 14 March 2014). 
who in consequence of the said Treaty have endeavoured to evert the nations claim of Right ${ }^{168}$ and to overturn not only the attainments of the late happy Revolution but the whole covenanted work of Reformation, to cut off all possible security for the subsisting of the church as now established by law by subjecting her with all her Rights and privileges to the will \& discretion of a new Government \& parliament composed of prelats and men prelatically affected and by opening a door to Toleration which in this church doth unavoidably tend to the breaking down of the hedge of discipline, the staining of the purity of Religion \& worship, the propagating of popery and all errour, the encouraging of all manner of Impiety and licentiousnes and the utter subversion of the present legal settlement by presbitery, and thereby to the involving of this Land under the most horrid guilt of national perjury, we being bound by the sacred engagement of most solemn covenants to maintain the Truth \& purity of Religion and the presbyterian government of the church as well as to preserve the Rights \& privileges of the parliament and the liberties of the kingdom. who have concealed their forsaid mischievous design and Treaty, wrapping it up in secrecy as a work of Darknes from the knowledge of the nation, (who had unquestionable Right to be acquainted therewith \& to give their sentiments thereupon befor any conclusion should be made in parliament,) till the very tyme of laying the same befor the parliament, ${ }^{169}$ where the wicked Faction having their prepared accomplices and abettors corrupting some and seducing others have precipitantly rushed into the ratifying and approving of the same, ${ }^{170}$ notwithstanding of the many earnest \& weighty Adresses \& Remonstrances made to the contrary by the commission of the General Assembly of this national church, by The convention of the Royal Burrows, and by all parts of the country, which have not hitherto been regarded, nor any respect had [for] the general dissatisfaction \& aversation that is testified against these courses all over the nation.

By all which \& many other treacherous \& undermining practices It is evident that the forsaid Faction hath sold us and our nation not only to be Bondmen \& Bondwomen ${ }^{171}$ but to be destroyed \&

\footnotetext{
${ }^{168}$ In his history, Walter Steuart of Pardovan explains that opponents of the treaty argued that incorporation was blocked by the Claim of Right's constitutional requirement for frequent parliaments, reinforced by the 1703 act of parliament defining any attack on the Claim of Right as treasonous. Steuart of Pardovan, 'A short account', NLS Wodrow Quarto LXXV, ff. 143-4; RPS 1703/5/190, 'Act ratifying the turning the meeting of the estates in the year 1689 into a parliament', 16 September 1703.

${ }^{169}$ This refers to the Court party's decision not to make printed copies of the treaty available before parliament opened on 3 October.

${ }^{170}$ This refers to a proposal made by Wylie in his July tract and pursued by the Country party in October to secure a recess for the consultation of constituents with the publishing of the terms of the treaty. Bowie, Scottish Public Opinion, 101-2, 117-8.

${ }^{171}$ This reflects a Biblical concept of 'bondmen', meaning those sold into slavery. The nation of Israel were understood to have been 'bondmen' to the Pharaoh. See, for example, Leviticus 25:41-43; Deuteronomy 6:21. The characterisation of incorporation as slavery can be found in other protests. In its address to parliament, the parish of Cambuslang considered incorporation an 'intire enslaving of our church and Nation'. NRS Supplementary Parliamentary Papers PA 7/28/56, Cambuslang. The inclusion of women suggests a nation in the Biblical sense of a people or tribe rather than a political nation of male freeholders. The rest of the
} 
perish in which the enemy with all their English associats can never be able to countervail the soveraigns Dammage ${ }^{172}$

For which cause We as true Scotsmen and christians under the sense of the Bonds of nature and our solemn oaths to the most high God do only [as] a least and unsatisfactory remedy ${ }^{173}$ betake ourselves to Arms, all means of Remeid ${ }^{174}$ to prevent our Ruine by supplication Argument \& protestation [and the] fair \& safe proposal of [a] present settlement of the succession being dispised and proving unefectual; ${ }^{175}$ to obtain so much as a short recess $\&$ delay at the hands of a resolved Faction sworn to destroy us \& our country; ${ }^{176}$ to stand for our lives, for our Religion and liberties, for the soveraignity and Independency of this Ancient free kingdom, that have been within these few years worthily asserted by this present parliament, ${ }^{177}$ and for the Being, Rights and priviledges of our parliament. Inviting all our countrymen, and particularly the gentlemen of [the] souldiery ${ }^{178}$ who are honest hearted Scotsmen and lovers of their country, their Religion \& the laws to concur and join with us in defence of their nation against the violence and Invasions of the forsaid treacherous Faction and all their supporters and in craving:

1. That the lamentable state of this Land may be freely and truly with all humility Represented to Her Sacred Majesty our Gracious protestant Queen Anne to whom we resolve with stedfast loyalty always to adhere as our undoubted soveraign rightfully Inheriting our crown, ${ }^{179}$ and are satisfied, upon Her Majesties decease (whom God long preserve) That, to the seclusion of all popish pretenders, the same be settled, by a free Act of our own parliament, upon the next heirs in the protestant line, with such conditions and provisions as a free parliament shall judge necessary to deliver this nation from English Influence and to secure our civil Rights and liberties, the Independency and soveraignity of the nation, and

document is stated in terms of 'Scotsmen', indicating that only men were expected to participate in the rising. Christopher Whatley has indicated the strength of female Presbyterian opposition to the treaty: Whatley, The Scots and the Union, 288.

${ }^{172}$ This word is partially obscured and the transcription is uncertain. An alternative reading is 'Dommayne'. In either case the author's meaning is not clear.

173 'Only [as] a least and unsatisfactory remedy' is a marginal addition. The reading of 'unsatisfactory' is uncertain.

${ }^{174}$ Remedy.

${ }^{175}$ This seems to refer to the resolves of November. It could refer to the intended protestation of 7 January, but it seems more likely that this paper was drafted in early December.

${ }^{176}$ This refers to the opposition's attempts to secure a recess at the opening of the session and on 15 November as discussed above.

177 This refers to the passage of the Act of Security in 1703 and 1704. It may also refer to the voting of monetary awards to James Hodges and James Anderson for patriotic publishing. RPS 1705/6/110, 'Procedure: debate over act of supply and priorities', 8 September 1705.

${ }^{178}$ As noted above, Wylie was involved in a scheme to encourage the officers of the Scottish regiments to address parliament against the treaty. This may also refer to the important role played by experienced army officers in early modern risings. Cunningham of Aiket had been a major in the army during the Nine Years' War.

${ }^{179}$ This emphasises the Revolution sympathies and unrevolutionary intentions of the actors. 
the presbyterian Government of the church as founded upon the claim of Right and established by Law.

2. That Her Majesty be rightly informed of the mischief and desolation which this Incorporating union wold bring us under either by enslaving us to England or by raising such confusion irritation \& Rage in case their union should break as to make way for introducing the person called K[ing] J[ames] the $8^{\text {th }} ;{ }^{180}$ we being fully perswaded of Her Majesties innate clemency, good mind and parental tenderness \& care towards all her subjects and that nothing but the misrepresentations of evil \& self-designing men have prevailed upon her princely Goodnes to give the least countenance to the said Incorporation we being also willing to enter into such such [sic] an union with our Brethren \& fellow subjects of England as may be just \& honourable, advantageous $\&$ safe to both nations.

3. we crave that the forsaid Incorporating union may be no further proceeded into, and that what is done therein may be declared to be, as it is in it self, void and null, being not only without the consent but contrary to the publickly expressed mind of the nation an overturning of all its fundamentals and an undermining and yeelding up of the honour, freedom and all the just Rights thereof. ${ }^{181}$

4. That all pensioners may be declared incapable of sitting and voting in parliament after the commendable example of England, who have done the same for the necessary preservation of their own constitution \& loyalties. ${ }^{182}$

5. That all those who have concurred to the Abolishing of Parliaments, by approving the $3^{d}$ Article of the Treaty, having thereby falsified their Trust, incurred the pains of Treason by law, and voted themselves out of doors, may be expelled, That the nation which disowns \& testifies against their perfidy may elect faithful men as their Representatives to be substituted in their stead. [A]nd That they together with these noble Lords, Barons and Burgesses true Scots patriots who have faithfully \& honestly dissented from and protested

\footnotetext{
180 'Either by enslaving ... K[ing] J[ames] the $8^{\text {th' }}$ is a marginal addition with no clear indication of where these words belong, but they appear to fit here. The idea that an unhappy union might strengthen the Jacobites was generated by reports that some Scots in the west believed 'it were better for church and state to bring ho[me the] Prince of Wales', who would only be king for a lifetime, than accept a 'perpetuall yock of prelacy and slavery'. D. Warrand (ed.), More Culloden Papers, 5 vols. (Inverness, 1925), ii, 9.

${ }^{181}$ This makes the radical suggestion that the ratification of the treaty in the parliament could be declared null on the basis that the votes were not in keeping with extra-parliamentary opinion. The idea that the legislation should be null because it abrogated fundamental law suggests a limitation on the power of parliament to change the constitution of the realm. Wylie had argued this in his July tract, attracting a response by George Mackenzie, earl of Cromarty in his A friendly return to a letter concerning Sir George Mackenzie and Sir John Nisbet's observation and response, on the matter of the union ([Edinburgh],1706). On this debate, see Bowie, Scottish Public Opinion, 94-5, 104; Jackson, 'Conceptions of Nationhood', 71-74; Kidd, Union and Unionisms, 87-93.

182 England's 1701 Act of Settlement (noted above) included a provision barring crown pensioners from being members of the House of Commons.
} 
against the said Treaty and the Articles thereof with Her Majesties High Commissioner, whose character as representing Her Royal person we honour till she shall be graciously pleased to conferr that high dignity upon another better deserving it, may compose a true loyal Scots parliament for securing fundamentals and settling all disorders, and differences in the nation to whose determinations we shall cheerfully submit.

We do profess and declare in the presence of God that we do not intend the least hurt or prejudice to any mans person or goods who shall not oppose us and our Righteous Cause, But we will defend and assert[,] in the strength and by the Assistance of the Almighty upon which alone we rely, The fundamental Rights, Laws and Constitution of this free monarchy, the privileges \& liberties of this church \& nation and our claim of Right, against the treacherous attempts \& invasions of the forsaid combined Faction \& all others, with our lives and Fortunes to the utmost, concluding with the words \& Resolution of our valiant Ancestors relating to their noble champion deliverer and protector K[ing] Robert Bruce. So long as an hundred Scotsmen remain alive, we will never be subjected any manner of way to the dominion of England. It is not for Glory, Riches and honours we fight; but for liberty, which no good man loseth but with his life.

[Endorsed in a different hand: Proposall 1707] ${ }^{183}$

${ }^{183}$ As noted above, while it is possible that the paper was drafted to support the walk-out planned by the duke of Hamilton for early January 1707, early December 1706 seems more likely. 